Estuarine, Coastal and Shelf Science

December 2016, Volume 182, Part A, Pages 60-71

http://dx.doi.org/10.1016/j.ecss.2016.09.003

http://archimer.ifremer.fr/doc/00350/46154/

(c) 2016 Elsevier Ltd. All rights reserved.

\title{
Brachyuran crab community structure and associated sediment reworking activities in pioneer and young mangroves of French Guiana, South America
}

\author{
Aschenbroich Adélaïde ${ }^{1,{ }^{*}}$, Michaud Emma ${ }^{1}$, Stieglitz Thomas ${ }^{2}$, Fromard François ${ }^{3}$, Gardel Antoine ${ }^{4}$ \\ ${ }^{5}$, Tavares Marcos ${ }^{6}$, Thouzeau Gérard ${ }^{1}$
}

${ }^{1}$ Laboratoire des Sciences de l'Environnement Marin (LEMAR, UMR 6539, CNRS-UBO-IRD-

IFREMER), IUEM, Rue Dumont d'Urville, 29280 Plouzané, France

${ }^{2}$ Centre for Tropical Water and Aquatic Ecosystem Research TropWATER, James Cook University,

Townsville Qld 4811, Australia

${ }^{3}$ Laboratoire d'Ecologie fonctionnelle et Environnement (ECOLAB, UMR 5245, CNRS-UPS-INPT),

Université Paul Sabatier, 118 Route de Narbonne - Bat 4R1, 31062 Toulouse, France

${ }^{4}$ Laboratoire d'Océanologie et Géosciences (LOG, UMR 8187, ULCO, CNRS, USTL), 32, Avenue Foch, 62930 Wimereux, France

${ }^{5}$ USR LEEISA (Laboratoire Ecologie, Evolution et Interactions des Systèmes Amazoniens), 275 route de Montabo, 97334 Cayenne, French Guiana

${ }^{6}$ Museum of Zoology, University of São Paulo, Avenida Nazareth, 481, 04263-000, Ipiranga, São Paulo, SP, Brazil

* Corresponding author : Adélaïde Aschenbroich, email address : adelaide.aschenbroich@gmail.com ;

emma.michaud@univ-brest.fr ; thomas.stieglitz@jcu.edu.au ; francois.fromard@univ-tlse3.fr ; antoine.gardel@univ-littoral.fr ; mdst@usp.br ; gerard.thouzeau@univ-brest.fr

\begin{abstract}
:
This study in French Guiana evaluates the changes of crab assemblages and their bioturbation activities between mangrove early stages (pioneer and young mangrove) and within stages by taking their spatial heterogeneity (tidal channels, flat areas, pools) into account. The results show differences in crab assemblage structure between and within the early stages of mangrove in relation to microhabitat and sediment characteristics. The sediment reworking rates are a function of the biomass or density of particular species (Ucides cordatus, Uca cumulanta) and burrower functional groups. Crab species or functional interaction mediate changes in sediment reworking rates suggesting the need to consider entire benthic communities rather than single species. This study suggests that the role of the microhabitat in determining the biologically-induced sediment reworking rates depended on the age of the mangrove. Feeding activity results in a sediment turnover of $11.7 \pm 9.7 \mathrm{gdw} \mathrm{m}-2$ day-1 and $6.8 \pm$ $3.0 \mathrm{gdw}$ m-2 day-1 in the pioneer and young mangroves, respectively. Burrow maintenance excavates $40.5 \pm 7.4 \mathrm{gdw} \mathrm{m}-2$ day-1 and $251.3 \pm 419.7 \mathrm{gdw} \mathrm{m}-2$ day-1 in the pioneer and young mangroves, respectively. Upscaling to the studied area (Sinnamary estuary: $6 \mathrm{~km} 2$ ), shows that 500 tons.day-1 and 20 tons.day- 1 of sediments could be excavated and pelletized, respectively, during the spring tides of the dry season. Thus, biological sediment reworking would greatly contribute to the sedimentary
\end{abstract}


dynamics of the Guianese mangroves under Amazonian influence.

Keywords : Mangroves, Crabs, Community composition, Bioturbation, French Guiana, Amazon 


\section{Introduction}

Benthic faunal activities regulate structure and functioning of mangrove forests through physical modification of the habitat, selective propagule predation, litter and organic matter processing (Kristensen 2008, Lee 2008, Nagelkerken et al. 2008). Ecosystem functioning is strongly influenced by bioturbation (biological perturbation of sediments) mostly by grapsid and ocypodid crabs considered to be "ecosystem engineers" (Kristensen 2008). Crabs induce sediment transport and mixing during burrow maintenance and feeding activities modifying sediment dynamics and food resource availability for the microbial, faunal and plant communities of mangroves and adjacent ecosystems (Botto and Iribarne, 2000; Botto et al., 2005; Kristensen and Alongi, 2006; Escapa et al., 2007, 2008). Despite its importance, the quantification of sediment reworking by crabs has been little studied in intertidal ecosystems, even less in mangroves, and has been mostly related to single species (Iribarne et al. 1997, Botto \& Iribarne 2000, Amouroux \& Tavares 2005, Penha-Lopes et al. 2009, Needham et al. 2010). In temperate environments, sediment reworking rates are a function of the density and size of small macro-invertebrates (Duport et al., 2006; Gilbert et al., 2007). Abiotic factors such as sediment grain size, cohesiveness, vegetation cover (Escapa et al. 2008, Needham et al. 2010) and sewage releases (Bartolini et al. 2011) modify both feeding and burrow maintenance rates of single crab species; but their species interactions may also mediate changes in ecosystem functioning (for smaller macrofauna: Cardinale et al. 2002, MermillodBlondin et al. 2005). Brachyuran crab assemblages in tropical intertidal systems vary with vegetation structure, sediment characteristics and food availability (Nobbs, 2003; Koch et al., 2005; Mokhtari et al., 2015). But, crab communities respond to mangrove development in different ways depending on plant species composition and habitat heterogeneity (Macintosh et al. 2002, Li et al. 2015). Indeed, habitat heterogeneity due to the presence of open and close canopy area, roots and channels within mangrove stands may induce spatial or temporal 
variations in crab assemblages through the modification of sediment properties (Koch et al., 2005; Bezerra et al., 2006; Diele et al., 2010). Organization of crab assemblages and associated bioturbation activities are expected to change with mangrove growth and spatial heterogeneity influencing their roles played in ecosystem functioning. These relationships remain not well understood, and are investigated here.

The study was carried out on the French Guiana coastline, which is part of the longest muddy coast in the world under the influence of the Amazon River sediment inputs (Anthony et al. 2010). Intensive coastal hydro-morpho-sedimentary processes promote rapid expansion of the mangrove associated with the settlement of mud banks (Fromard et al. 1998, Anthony et al. 2010). The coastal dynamic, through the mud accretion, compromises the accessibility of the shoreward mangroves. For this reason, coastal research in French Guiana has been mainly based on remote sensing (e.g. Gardel \& Gratiot 2005; Gardel et al., 2011; Gensac et al., 2011). Biological and field-based mangrove studies are rather rare and mostly deal with vegetation and sedimentary organic matter dynamics (Fromard et al., 1998, 2004; Marchand et al., 2003); thus, the assessment of Brachyuran crab communities' structure and bioturbation activity in mangrove under the Amazonian influence is of valuable interest. Amouroux \& Tavares (2005) preliminary showed that in these highly resilient mangroves, the crab species richness is lower than in other mangroves not subjected to Amazonian sediment inputs. They propose that the short period of stability between successive processes of erosion and accretion along the coast of French Guiana and the monotonous sedimentary bottoms (Amazon River clay and mud discharges) may prevent the most sensitive species from establishing themselves. The present study further hypothesizes that rapid mangrove growth as well as spatial heterogeneity (i.e. microhabitats) affect the crab community structure and its subsequent sediment reworking activities. Specifically, (1) surface sediment parameters and crab structural and functional assemblages are characterized in relation with mangrove age 
and microhabitats and (2) sediment reworking rates by different crab communities are quantified.

\section{Material and methods}

\subsection{Study area}

The pioneer and young stages of mangrove (hereafter referred as 'sites') targeted for this study are located on the northeastern part of the mouth of the Sinnamary estuary in French

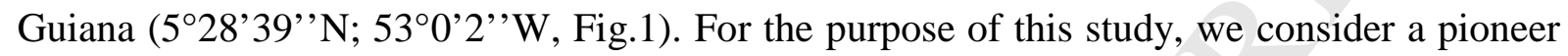
and a young mangrove system with trees around $1 \mathrm{~m}$ and $6 \mathrm{~m}$ height, respectively, representing tree age of around 6 months and 2 years and tree density around 150-300 ind.ha ${ }^{-1}$ and 600010000 ind.ha $^{-1}$, respectively (Fig.1; Fromard et al. 2004). Sampling was carried out during a spring tide of the dry season (3-8 November 2014). The mud bank topography over which the forest develops parallel to the shoreline is very smooth (1:2000; Gardel \& Gratiot 2005). Pioneer and young mangroves grow on a sedimentary bed which elevation slightly varies from 2.6-2.8 $\mathrm{m}$ and 2.7-2.95 above the hydrographic zero, respectively (Proisy et al. 2009). The tide is semidiurnal with spring and neap high tide water levels up to $3.2 \mathrm{~m}$ and $2.5 \mathrm{~m}$ respectively. The study sites were thus inundated during spring tides but not inundated for 4-5 days during neap tides.

It is important to note that the presence and considerable dynamics of local mud banks severely compromise access and thus choice of field sites in these settings. In this light, any data collected at such sites must be considered valuable. In particular early stages of mangrove are located shoreward, in remote locations. They can be accessed during high tide only reducing the number of field-based studies on these systems in French Guiana (Gardel \& Gratiot 2005). The study area can be reached with more than $2.7 \mathrm{~m}$ water height only (i.e. during 6 days) along a channel (arrow, Fig.1A) which drained both a pioneer stage and a young stage of mangrove located nearby. Other early stages of mangrove development in this 
zone were not accessible due to continuous deposition of mud (e.g. at the west of the

117 Sinnamary estuary, Fig.1A).

118 The substrate is characterized by microhabitats reflecting changes in hydrological and

119 topographic conditions. In the pioneer mangrove, the mud flat area exhibited pools and tidal

120 channels whereas in the young mangrove, only flat areas and tidal channels occurred. Aerial

121 pictures at high spatial resolution $\left(27 \mathrm{~cm} \cdot\right.$ pixel $\left.^{-1}\right)$ taken in November 2013 were beforehand

122 digitalized with ArcGis ${ }^{\circledR}$ software in order to quantify the relative surface, density and

123 dimensions of each microhabitat. Tidal channels, flats and pools represented $5.2 \%, 89.6 \%$ and

$1245.1 \%$, respectively of the pioneer mangrove surface, whereas tidal channels and flat areas

125 represented 5.2 and $94.8 \%$, respectively of the young mangrove ground surface (no pools

126 present). Tidal channels of 0.4-2 $\mathrm{m}$ width were spaced out from 4 to $40 \mathrm{~m}$ in both stages.

127 From 20 to 100 pools.ha ${ }^{-1}$ of $0.4-5.5 \mathrm{~m}$ diameter composed the pioneer mangrove.

129 Due to the spatial and temporal constraints in access to field sites previously described, only

130 one pioneer and one young mangrove were considered. In order to describe intra-site

131 variability due to spatial heterogeneity, pools, tidal channels and flat areas (hereafter referred

132 as "microhabitats") were studied on the same tidal level within sites. In the pioneer mangrove,

133 sampling of crab species was carried out in nine $1-\mathrm{m}^{2}$ plots on the edge of three pools (1 plot

134 per pool), on the edge of three tidal channels (1 plot per channel), and on three flat areas (1

135 plot per flat). In the young mangrove, six $1-\mathrm{m}^{2}$ plots were investigated, on the edge of three

136 tidal channels (1 plot per channel) and on three flat areas (1 plot per flat), respectively (Fig.2).

137 At least 10 meters separated two individual sampling plots thus ensuring spatial

138 independence, assuming territory ranges of few square meters for adult intertidal crabs

139 (Cannicci et al. 1999, Nordhaus et al. 2009). 
142 Sediment samples were collected to characterize the physical properties of surface sediments

143 (grain size, water content and porosity) and to quantify food resources: chlorophyll- $a$ (Chl-a),

144 phaeopigments (phaeo) and particulate organic carbon and nitrogen (POC and PON).

145 Sediment pore-water was extracted in situ to measure salinity using a refractometer at a

146 precision of \pm 1 ppt (Practical Salinity Scale) (Marchand et al. 2004). Samples were randomly

147 collected in triplicates inside each plot, except for POC and PON (one replicate per plot)

148 (Table 1). Each replicate consisted of three $3 \mathrm{~cm}-\varnothing \times 1 \mathrm{~cm}$-depth cut-off syringe imprints (total

149 area: ca. $21.2 \mathrm{~cm}^{2}$ ). In order to evaluate the amount of mangrove-derived litter available as

150 food resource and to cue the variation in sediment structural complexity, the litter was

151 collected from the entire plots, and above-ground pneumatophores were cut and collected in

$1521 / 4$ of each plot for further biomass (litter) and density (pneumatophores) quantification.

154 Black-grey-colored sediment mounds near burrow openings which were excavated by crabs

155 from depth during burrow maintenance were sampled (i.e. excavated sediment) (Botto \& 156 Iribarne 2000). Feeding pellets, i.e. non-ingested particles shaped into small irregular balls 157 after extraction of organic matter from the substrate, were sampled separately (Miller 1961; 158 Botto \& Iribarnes, 2000). Just before the incoming tide covered the sampling area, all 159 excavated sediment and feeding pellets were collected in each plot using a small steel spatula, 160 stored in separate vials and kept frozen until analysis.

\subsubsection{Crab collection}

162 The efficiency of various sampling strategies for mangrove crabs has been widely discussed in the literature (Nobbs \& McGuiness 1999, Skov \& Hartnoll 2001; Skov et al. 2002, Ashton et al. 2003; Kent \& McGuinness 2006). These authors agree that unbiased sampling of 
sediment excavation and sorting. Visual counts underestimate the most cautious species, prevent species identification and biomass measurements whereas burrow counts overestimate crab abundances during spring tides as crab burrows may have high turnover (Skov \& Hartnoll 2001, Skov et al. 2002). Traps register crab activity rather than density and are avoided by some species (Lee 1998). In this study, both the sediment processed by crabs and the crabs themselves had to be collected in the same plots; hand-catching was chosen for this purpose. This alternative method is commonly used in mangroves (Macintosh et al. 2002, Ashton et al. 2003, Amouroux \& Tavares 2005, Mokhtari et al. 2015). It is less laborintensive, thus more replicable and more practicable than the sediment excavation-sorting method, which is difficult to carry out in sediments that are penetrated by roots or in nearfluid mud. In this study, pneumatophore density ranges did not impede collecting crab from their burrows between the pneumatophores (Fig.1D). A time-based sampling method modified from Ashton et al. (2003) was used in the present study to estimate crab community structure and allow meaningful data comparison between plots. Although hand-catching generates relative rather than absolute community structure estimates per unit effort, the ratio between investigation time and sampling unit size was chosen to optimize sampling efficiency. In order to reduce bias towards common or slow-moving crabs, the crab seeking time was thus increased to $30 \mathrm{~min}$ and the sampling unit size decreased to $1 \mathrm{~m}^{2}$ (vs. $15 \mathrm{~min}$ and $33 \mathrm{~m}^{2}$, in Ashton et al., 2003). Each replicate represented three persons (always the same) hand-catching crabs from burrows and sediment within $1-\mathrm{m}^{2}$ plots during $30 \mathrm{~min}$. Crabs were stored in a $70 \%$ ethanol solution until identification, counting and biomass measurement.

\subsection{Sample analysis}

\subsubsection{Environmental parameters}

Grain size fractions were analyzed with a Malvern Mastersizer-S2000. Prior to analysis, organic matter was removed and aggregated particles were deflocculated following Sperazza 
et al. (2004). Grain size fractions were quantified as clay, mud (very-fine, fine and medium

192 silts), coarse silt and very fine sand; median grain size was assessed. Sediment density $(\delta)$ was

193

194

195 determined from the wet mass $(\mathrm{m})$ of a known volume $(\mathrm{V})$ of sediment $(\delta=\mathrm{m} / \mathrm{V})$. Water content was measured by sample weight loss after freeze-drying for 72 hours. Sediment porosity $(\phi)$ was estimated as $\phi=(\delta \times$ water content $) / 100$ (Kristensen and Alongi, 2006). Pigments were analyzed with a protocol adapted from Lorenzen (1966) and Buffan-Dubau \& Carman (2000): Chl-a was extracted from freeze-dried sediments in $90 \%$ acetone. Concentrations were determined on a Turner 10-AU fluorometer, using an acidification step to separate phaeopigments from photosynthetic pigments. Phaeo:Chl-a ratio was calculated to assess phytodetritus degradation state. Total carbon and nitrogen were analyzed by combustion at $930^{\circ} \mathrm{C}$ on a CHN carbon analyzer (FLASH-2000). The inorganic fraction was obtained from acidified (HCL, 1N) aliquots and the organic fraction from the difference between both fractions after Hedges \& Stern (1984). The pneumatophores were counted and the litter biomass was estimated by weighing samples previously dried at $60^{\circ} \mathrm{C}$ until constant weight.

\subsubsection{Biologically reworked sediment}

Excavated sediment and feeding pellets were freeze-dried for $72 \mathrm{~h}$. Previous studies on the behavior of fiddler and Ucides crabs showed that they concentrate most of their burrowing activity in the first low tide hours (Eshky et al. 1995, Nordhaus et al. 2009). In contrast, they feed at a consistent rate over time (Eshky et al. 1995, Bartolini et al. 2009). The quantification of excavated sediment at the end of the low tide is assumed to represent the accumulated low tide activity. Feeding pellets weights were linearly standardized to the total low tide activity period. Rates of excavation and pelletization were standardized per day $\left(\mathrm{g}_{d w} \cdot \mathrm{m}^{-2} \cdot \mathrm{day}^{-1}\right)$. 
215 All crab individuals were identified to the lowest practicable taxonomic level. Since most

216 fiddler crabs with a carapace length less than $6 \mathrm{~mm}$ are difficult to identify at species level

217 they are referred as "juveniles" (for classification purposes only). In order to define allometric

218 relationships, crab subsamples were used to relate individual carapace width and length to

219 their biomass $\left(\mathrm{Bm} ; \mathrm{g}_{d w}\right)$. Biomass was estimated by weighing individuals dried at $60^{\circ} \mathrm{C}$ until

220 constant weight. Species were clustered per functional groups i.e. groups of species exhibiting

221 similar burrowing activity (bulldozer, burrower, non-burrower) based on literature data.

222 Primary community variables for crab community description included crab density (D;

223 ind. $\mathrm{m}^{-2}$ ), species richness $(\mathrm{S})$ and functional richness ( $\mathrm{F}$; number of group) and biomass (Bm; $\left.224 \mathrm{~g}_{d w} \cdot \mathrm{m}^{-2}\right)$.

\subsubsection{Species richness and representativeness}

227

In order to compare the crab species richness between sites and to estimate the representativeness of sampling effort, rarefaction curves were used. It allows comparing the species richness between groups despite unequal sample sizes (Gotelli \& Colwell 2001) by estimating a species' number as a function of the accumulated number of individuals sampled. The comparison between samples was made for the lowest total number of individuals in common between sites or microhabitats. Extrapolated curves were drawn as a function of sampling area to evaluate the sampling effort needed to reach an expected maximum species richness (Colwell et al. 2012). Relationships between crab carapace size and biomass were explored by regression analysis, and best-fit models were retained. Relationships obtained from 205 individuals were used to estimate the biomass of the remaining 294 individuals collected.

\subsubsection{Univariate analyses}


Differences of environmental and community variables between sites (pioneer, young

240 mangrove) and between the microhabitats within sites (pools, tidal channels, flat) were

241 explored by analysis of variances. To satisfy homoscedasticity and normality requirements,

242 Chl-a, \% coarse silt and \% very-fine sand were previously $1 / x$-transformed while excavation

243 and pelletization rates were $\log (\mathrm{x}+1)$-transformed. Parametric analyses (ANOVA) and

244 pairwise comparison tests (Tukey's HSD Post-hoc) were then applied to these variables.

245 Differences in mud content, pneumatophore density, litter biomass, POC, PON, and C:N

246 ratios between sites were tested using the non-parametric analysis of variances (Kruskal-

247 Wallis test) due to non-homoscedasticity of the data.

\subsubsection{Multivariate analysis}

A permutational multivariate analysis of variance based on density and biomass matrices (PERMANOVA; Anderson 2001) was computed to test the multivariate response of crab assemblages to the site and microhabitat factors. A co-inertia analysis was performed to visualize the distribution of crab species in space and in relation to the environmental variables. This two-tables ordination method correlates the structures of the biological and environmental data and clusters samples, according to both their fauna and environmental characteristics, when the tables have different numbers of environmental variables, species and/or samples (Doledec \& Chessel 1994). The relatedness of the two datasets was measured by the multivariate coefficient of correlation (RV). For all multidimensional analyses, faunal data were first Hellinger-transformed avoiding bias towards rare species when analyzing species abundance and biomass (Legendre \& Gallagher 2001).

\subsubsection{Correlation between sediment reworking and crab community variables}

Correlation analyses were used to explore if the sediment reworking rates were significantly and positively associated with 1) the crab density, biomass, species and functional richness; 2) the density or biomass of particular species that could drive the rates; and 3) the density or 
264 biomass of functional groups that would suggest an interactive effect of species within groups on such process. All relationships were tested with Pearson's multi-correlation analysis after data homogeneity verification.

\section{Results}

\subsection{Surface sediment characterization}

Sediments are the wettest and saltiest in the young mangrove (Table 1). In the young mangrove, sediments with the lowest water content (37\%) and pore-water salinity (28.7) are on the tidal channel edges. In contrast, sediments with the lowest water content (32\%) in the pioneer mangrove are located on the flat and associated with the highest salinity (38.3). The pneumatophores density and litter biomass are significantly greater in the young mangrove. Chl-a, POC and PON concentrations are significantly higher in the pioneer mangrove, where microhabitats drive significant changes in POC and Chl-a concentration. The Phaeo:Chl-a ratio decreases close to pools and tidal channels in both mangrove stages.

\subsection{Crab community structure}

\subsubsection{Species and functional groups}

A total of 504 crabs were collected with 11 species identified. The genus $U c a$ is the most represented with 452 individuals belonging to 5 species; 226 individuals were grouped as $U c a$ spp juveniles. Adults of Uca spp and Ucides cordatus are herein clustered into 'small burrowers' and 'large burrowers', respectively. They excavate sediment from burrows during maintenance and induce a passive downward transport when they abandon their burrows (Kristensen 2008, Nordhaus et al. 2009). Grapsids, xanthids and juveniles of Uca spp are 'non-burrowers' (Crane 1975, Von Hagen 1977). Callinectes bocourti is a 'bulldozer' inducing turbulent biodiffusion when burying at the sediment surface (Bellwood 2002).

\subsubsection{Species richness and representativeness}


Considering both mangrove sites and the lowest total number of individuals between both sites $(n=130)$, the rarefaction curves (Fig. 3A) indicate an estimated species richness 2-fold higher in the young mangrove $\left(S_{(130)}=8.2\right)$ than in the pioneer mangrove $\left(S_{n(130)}=4\right)$. The extrapolated rarefaction curve (Fig. 3B) indicates that a maximum taxa richness of 24 species would be reached in $70 \mathrm{~m}^{2}$ of investigation. Maximum species richness $(100 \%)$ is reached from the five plots in the pioneer mangrove, whereas in the young mangrove (Fig. 3A), the 6 plots sampled account for $37.5 \%$ of the total biodiversity. The flats and the tidal channels of the young mangrove support the highest $\left(S_{(37)}=4.5\right)$ and the lowest $\left(S_{(37)}=2.5\right)$ crab species richness, respectively (Fig. 3C). Rarefaction curves show that on the flat and pool edges of the pioneer mangrove the maximum estimated species richness is reached from the second sample (Fig. 3C). The crab community is dominated by small individuals with carapace width $<10 \mathrm{~mm}$ and carapace length comprised between 8 and $18 \mathrm{~mm}$ (Fig.4); carapace length of Uca spp is positively and significantly related to individual biomass $(p<0.001)$.

\subsubsection{Crab-environment relationships}

No significant difference exists in total crab abundance, biomass species and functional richness, between mangrove sites and microhabitats. Mean crab density is $25.6 \pm 2.5$ and 41.0 \pm 8.0 ind. $\mathrm{m}^{-2}$ on the tidal channel edges of the pioneer and young mangroves, respectively (Fig. 5A). Mean biomass ranges from $1.5 \pm 0.5 \mathrm{~g}_{d w} \cdot \mathrm{m}^{-2}$ (pool edges of the pioneer mangrove) to $27.7 \pm 44.3 \mathrm{~g}_{d w} \cdot \mathrm{m}^{-2}$ (flat of the young mangrove; Fig. 5B).

The co-inertia analysis differentiates sites both in terms of faunal composition and environmental parameters (Fig. 6); both matrices are significantly correlated $(\mathrm{RV}=0.72 ; p=$ 0.01). The pioneer mangrove samples (left cluster) differ from the young mangrove samples (right cluster) due to variations in Phaeo:Chl-a ratios, mud content, POC, PON, pore-water salinity and Chl-a along the F1 axis (Fig. 6A\&B) which explained $84.4 \%$ of the variance. Sites also significantly differ in crab community structure (PERMANOVA; abundance: $p=$ 
0.001; biomass: $p=0.007$; Fig. 6A) due to significant changes in Goniopsis cruentata, Uca maracoani, Uca mordax and Uca cumulanta density and biomass (ANOVA, $p<0.05$; Fig. 6). Also, the small burrowers density is significantly higher in the young mangrove than in the pioneer mangrove (ANOVA; $p=0.001$ ). The ordination diagram (Fig. 6B) suggests significant associations between species and sediment parameters (Table 2).

Samples within the young mangrove are separated along axis F2 but are not clustered according to microhabitats ( $p=0.4$; PERMANOVA; Fig. 6). Crab assemblages are different between microhabitats in the pioneer mangrove (at $p=0.058$; PERMANOVA) due to higher

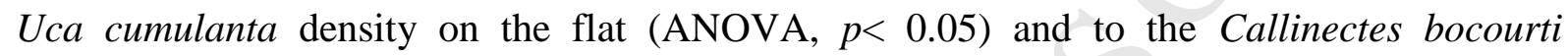
presence at pools and tidal channels microhabitats, in relation to the nature of the organic matter and the salinity (F1 axis; Fig. 6).

\subsection{Sediment reworking activity}

Sediment reworking activity is dominated by excavation (Fig. 7). High variability in excavation rates precludes significant difference between sites. Mean excavation rates are 251.3 \pm 419.7 and $40.5 \pm 7.4 \mathrm{~g}_{d w} \cdot \mathrm{m}^{-2} \cdot \mathrm{day}^{-1}$ in the young and pioneer mangrove, respectively. In order to estimate excavation by small burrowers only, the plot containing Ucides cordatus is excluded and mean excavation rate in the young mangrove becomes $9.1 \pm 7.6 \mathrm{~g}_{d w} \cdot \mathrm{m}^{-2} \cdot \mathrm{day}^{-1}$. Pelletization rates are $6.8 \pm 3.0$ and $11.7 \pm 9.7 \mathrm{~g}_{d w} \cdot \mathrm{m}^{-2} \cdot \mathrm{day}^{-1}$ in the young and pioneer mangrove, respectively. Sediment reworking rates were microhabitat-dependent only in the pioneer mangrove (Fig. 7) where excavation is the lowest at the pool edges $\left(3.78 \pm 1.4 \mathrm{~g}_{d w} \cdot \mathrm{m}^{-2} \cdot \mathrm{day}^{-1}\right.$; Tukey's HSD, $p<0.01)$ and the highest on the flat $\left(49.91 \pm 68.2 \mathrm{~g}_{d w} \cdot \mathrm{m}^{-2} \cdot \mathrm{day}^{-1}\right)$.

Over the study area, variations in sediment reworking rates are related to total biomass (Table 3) but not to density, species and functional richness. Excavation rates are correlated with densities of Ucides cordatus in the young mangrove ( $\mathrm{r}=0.99, p<0.001)$ and Uca cumulanta in the pioneer mangrove ( $\mathrm{r}=0.72 ; p=0.029$; Table 3$)$. The sum of small burrowers species is 
positively correlated with the excavation rates in both the young (density and biomass; $r>$ $0.89 ; p<0.02$ ) and pioneer (density; $\mathrm{r}=0.77, p=0.016$ ) mangroves (Table 3 ).

\section{Discussion}

\subsection{Methodological considerations}

\subsubsection{Study design}

In order to identify the fauna influencing the sediment reworking rates, the same plots have to be investigated twice: for the biologically-excavated/pelletized sediment and for crab collection. Although the investigation of large plots (Macintosh et al. 2002, Ashton et al. 2003) enables encompassing species-specific spatial variability of crab distribution, it leads to the disturbance of the sampling area during the sediment sampling and bias the crab community structure. Field constraints allowed the investigation of 3 replicate plots of $1 \mathrm{~m}^{2}$ per microhabitat. In similar works, the sampling designs used for crab sediment reworking estimates are similar (6 x $0.25 \mathrm{~m}^{2}$ : Needham et al. 2010; $2 \times 0.25 \mathrm{~m}^{2}$ : Bartolini et al. 2011) or are assessed targeting a specific number of burrow openings (Botto \& Iribarne 2000, Gutiérrez et al. 2006). The sampling strategy employed and the results obtained herein are thus comparable to previous studies.

\subsubsection{Spatial sampling representativeness and limits}

Most of the sediment surface characteristics do not deviate more than $20 \%$ from the mean highlighting a low intra-microhabitat variation in our study. Results show however that the variations in the structural complexity (pneumatophores), physical sediment characteristics (salinity, grain size, water content) and organic matter resources are important between pioneer and young mangroves and microhabitats, and determine crabs distribution (Table 2; Fig. 6; cf. Bertness \& Miller 1984, Kon et al. 2010, Mokhtari et al. 2015). Significant environmental modifications between sites and microhabitats justify the habitat distinction made for the exploration of a potential context-dependent crab effect on sediment reworking. 
The rarefaction curves show that the sampling regime employed in this study adequately describes the crab biodiversity in the pioneer mangrove area. In contrast in the young mangrove the species richness is not fully described. Larger sampling units are required for the study of larger-sized species such as Ucides cordatus present in low frequency (Koch \& Wolff 2002, Nordhaus et al. 2009, Ferreira et al. 2015). Size structure of Uca spp, the most abundant genus of the study site, is homogeneous over the study area, which is representative of fiddler crab populations (Diele \& Koch 2010). Additional grapsids species can be expected in the young mangrove (Aratus pisonii, Pachygrapsus gracilis; Amouroux \& Tavares 2005). As non-burrowers, these species probably do not contribute to the sediment reworking (Von Hagen 1977).

The application of rarefaction analyses is instructive in comparing biodiversity under varying sampling size or efficiency and in optimizing further sampling design (Dittmann 1995; Huang et al. 2012), notably after the current first study about the Guianese mangrove crab community structure.

Despite its limitations, the study design applied herein demonstrates an increase in crab diversity from the pioneer to the young mangrove, based on a common number of individuals. Since all plots were investigated in the same way, they can be compared and the relationships between particular crab assemblages and sediment reworking rates remain valid.

\subsubsection{Temporal setting of the study}

The geographical setting allowed spring tide investigations only. However, as most previously published works focused on spring tides, our results are meaningfully comparable with previous works. We consider the spring tide bioturbation rates as a maximum, with lower rates during neap tides chiefly for two reasons (a) the phreatic water level sought by many burrowers to maintain humidity in burrows is deeper during spring tides, which can result in an increase in the total excavation rate up to 15-fold (Iribarne et al. 1997; Tavares unpubl), 
even if some species may dedicate less time to burrow maintenance when the sediment is frequently flooded (Nordhaus et al. 2009); (b) during neap tides, the sediments are drier and harder, resulting in reduced excavation and pelletization activities (Kim et al. 2004, Gutiérrez et al. 2006). Beyond tidal cycles, bioturbation activities may slightly vary across seasons. Precipitation runoff has been suggested to increase sediment deposition into burrows enhancing burrow maintenance activities during neap-tides (Gutiérrez et al. 2006).

\subsection{Environmental conditions in early mangrove development stages}

Variation in median grain size is negligible between sites and reveals the monotonous finedgrain habitat of the studied area as a result of the recurrent mud Amazonian inputs (Debenay et al., 2007; Anthony et al., 2010). However, increase in pneumatophores density in the young mangrove may cause small-scale turbulence facilitating sedimentation of fine fraction which explains the higher mud content at this site (Kathiseran, 2003). The equatorial Amazonian region is influenced by low coastal salinity due to high river discharge and rainfall intensity which can result in modified benthic fauna assemblages compared to other latitudes (eg. Bernardino et al., 2015). However, pore-water salinities and water contents exhibit significant variations between mangrove sites. The closed canopy in the young mangrove is likely to prevent water evaporation from the sediment, lowering soil salinity compared to the pioneer mangrove despite salt exclusion by pneumatophores (Scholander et al., 1968).

In an earlier work, pioneer and young mangroves were differentiated from mature and senescent mangroves in terms of sedimentary organic matter nature. It is originated by algae in the earliest stages of mangrove and derives from vascular vegetation in the older stages as the tidal inundation frequency decreases and the litter exportation rate decreases (Marchand et al., 2003). However, the nature of the resources differed also between and within early stages of mangrove development with a decrease in labile organic matter content and an increase in the litter biomass as mangrove tree densify and the benthic sunlight exposure decreased. 
Interestingly, the microhabitats are not discriminated in the same way according to the stage of mangrove development suggesting that impact of the morpho-sedimentary heterogeneity on habitat conditions evolves in parallel to the mangrove growth. For instance, the tidal channel and the pool edges in the pioneer mangrove exhibit lower pore-water salinity and higher water content than the flat areas, contrarily to the young mangrove. In the latter site, the tidal channels create thinning area where pore-water is likely to evaporate compared to the flat area. Small-scale environmental variability is likely to be equally or more important in structuring many benthic assemblages than large-scale processes (Chapman et al., 2010).

\subsection{Factors regulating crab community structure}

\subsubsection{Stage of mangrove development}

While total crab abundance and biomass are comparable between pioneer and young mangroves, results indicate clear variations in habitat characteristics contributing to changes in crab community composition. Uca mordax and Uca cumulanta, associated with shaded areas (Amouroux \& Tavares 2005), are more abundant in the young mangrove, together with the litter-feeder Ucides cordatus (Nordhaus et al. 2009). Structural supports created by the pneumatophores in young mangroves could favor the presence of some fiddler crabs such as U. mordax (Crane, 1975; Bertness \& Miller 1984). Uca maracoani is exclusive to the sunlight-exposed and highly-saline sediments of the pioneer mangrove (Crane 1975, Koch et al. 2005; Bezerra et al. 2006) likely due to successful larval survival and juvenile development in such conditions (Hirose \& Negreiros-Fransozo 2008). The presence of the tree climbing Goniopsis cruentata juveniles in the pioneer mangrove stage is interesting to note (cf. Amouroux \& Tavares 2005) in contrast with its previously reported preference for fully developed mangrove forests (Von Hagen, 1977; Diele et al., 2010). Pioneer stage may act as recruitment areas for juveniles whose maturation and behavioral changes may parallel the rapid evolution of the pioneer stage into a denser mangrove stand. 
439 Morpho-sedimentary heterogeneity determines crab species distribution only in the pioneer mangrove. A number of habitat specific associations for certain crab species may contribute to these differences: (a) the presence of pools and tidal channels favors the occurrence of the swimming predator and euryhaline Callinectes bocourti (Buchanan \& Stoner 1988, Diele et al. 2010), and (b) the comparatively drier sediment on the tidal flats may favor Uca cumulanta occurrence reducing the burrow maintenance cost compared to more fluid matrices (Bertness \& Miller 1984). Lower Chl- $a$ and higher Phaeo:Chl-a ratio simply reflect the labile organic matter impoverishment due to $U$. cumulanta grazing on the flat.

In the young mangrove, crab assemblage structure is similar between microhabitats. Further studies are required to determine if the consideration of the lacking species may change this pattern.

\subsection{Main contributors to sediment reworking}

The large burrower Ucides cordatus drives the sediment excavation process in the young mangrove in relation to its large size and biomass. However, both in the pioneer and young mangroves, the strong correlations between the total density of the small burrowers and the excavation rate suggest also their significant contribution to this process. Despite higher densities in the young mangrove, small burrowers rework less sediment in the young $\left(9 \mathrm{~g}_{d w} \cdot \mathrm{m}^{-}\right.$ $\left.{ }^{2} \cdot \mathrm{day}^{-1}\right)$ than in the pioneer mangrove $\left(40 \mathrm{~g}_{d w} \cdot \mathrm{m}^{-2} \cdot \mathrm{day}^{-1}\right)$. This contrasting activity level may result from functional variability in response to environmental factors and/or biological interactions (Cardinale et al. 2002, Mermillod-Blondin et al. 2005): in the young mangrove, 1) interactions between Uca cumulanta, Uca mordax and/or Ucides cordatus may have a negative effect on the sediment reworking performance of the small burrowers and 2) higher density of this functional group may alter individual behavior. Crab proximity may increase 
males waving, courtship and combat duration, thus decreasing the time allocated to burrow

463

464

465

466

467 maintenance.

Variations in sediment reworking rates are neither related to changes in species nor in functional richness per se but rather depend on the presence of an individual species or a specific burrowing behavior. These findings add weight to the recognition of the importance of species or functional identity in controlling ecosystem processes (Mermillod-Blondin et al. 2005; Gagic et al. 2015).

4.5. Sediment reworking rates in relation to mangrove stage and microhabitat

The sediment reworking rates between sites are not significantly different because of their high variability in the young mangrove. But the presence of large Ucides cordatus, despite its low density, enhances excavation rates in the young mangrove. This may suggest an increasing role of the crab community for the sediment reworking function when the ecosystem grows.

Further, our results suggest that, in the young mangrove, crab assemblages show functional similarities in response to structural consistency between microhabitats despite environmental differences. However, further verification of the microhabitat-dependence of the behavior of this Ucididae is needed.

The high density of Uca cumulanta enhances 10-fold the excavation rates on the flat compared to those on pools and channels in the pioneer mangrove, which is consistent with the observations by Escapa et al. (2008) in an estuarine salt-marsh. In the current study, mostly non-burrowing species inhabit large and inactive burrows located on the tidal channel and pool edges, which reduces sediment reworking activities. Overall, these results indicate the habitat specificity of the biologically-induced particulate transfer in pioneer mangroves and thus the context-specific role of microhabitats in determining ecosystem functioning. 
Sediment reworking rates estimated in this study are lower than those found in previous studies using similar sampling methods. Mean excavation rates in the young mangrove of French Guiana are 2-4 times lower than rates resulting from single species in other tropical salt-marshes and estuarine mud flats (ca. $550 \mathrm{~g}_{d w} \cdot \mathrm{m}^{-2}$.day ${ }^{-1}$; Botto \& Iribarne 2000, Gutiérrez et al. 2006; ca. $960 \mathrm{~g}_{d w} \cdot \mathrm{m}^{-2} \cdot \mathrm{day}^{-1}$, Needham et al., 2010). On the contrary, Bartolini et al. (2011) who summed up the reworking activity of two fiddler crab species in pristine Kenyan mangroves found excavation rates (ca. $10-20$ g.m $\mathrm{m}^{-2}$.low tide ${ }^{-1}$ ) similar to the excavation rates due to the small burrowers in the present study. Also, mean pelletization rates $\left(7-12 \mathrm{~g}_{d w} \cdot \mathrm{m}^{-}\right.$ ${ }^{2} \cdot$ day $^{-1}$ ) in the current study are much lower than the ones induced by Uca uruguayensis in Argentinian mud flats $\left(114.3 \mathrm{~g}_{d w} \cdot \mathrm{m}^{-2}\right.$.day ${ }^{-1}$; Botto and Iribarne, 2000) or due to Uca inversa and Uca annulipes in a Kenyan mangrove (ca. $160 \mathrm{~g} d w \cdot \mathrm{m}^{-2} \cdot 1$ low tide ${ }^{-1}$, Bartolini et al. 2011). Discrepancies in sediment rates may result from environmental variations such as tidal exposure time, type of vegetation cover and grain size (muddy vs sandy), from specific differences in burrow maintenance and feeding activities, and/or from species interactions. These previous studies quantified the activity of the dominant one or two crab species only, thus how differences in crab community structure might explain such sediment reworking discrepancies between studies cannot be deduced.

Diminution in species or functional richness may alter the sediment reworking rates or other ecosystem functions (Hooper et al. 2005). For instance, the variations between crab diversity at a global scale (between Atlantic-Pacific and Indo-Pacific mangroves) may modify the intensity of leaf consumption (Lee 2008). This study, in agreement with Amouroux \& Tavares (2005), suggests lower crab species richness in the French Guianese mangrove than in other West-Atlantic mangroves (Diele \& Koch 2010, Colpo et al. 2011), which could result in reduced sediment reworking rates. The uniform muddy soil texture, the short period of stability between erosion and accretion phases, and the low tree diversity due to high- 
512 frequency coastal dynamics along the French Guianese coast likely affect the establishment of

513 some crab species (Amouroux \& Tavares 2005, Ellison 2008). Further temporal and spatial

514 surveys are however needed to fully understand lower crab diversity in French Guiana

515 mangroves. However, at the study site scale, the biomass and the density of the small and

516 large burrowers, whatever the numbers of species present are the best predictors of the

517 aggregated bioturbation activities. The representative size structure of $U c a$ genus observed

518 over the study area confers reliability of the sediment reworking rates associated with the

519 small burrowers. Studies relating the whole crab community to sediment reworking are

520 required in order to better understand the biodiversity-ecosystem function relationships under

521 varying biotic and abiotic interactions in mangrove ecosystems.

522 Assuming spatial and temporal bioturbation rates being homogeneous during spring tides,

523 crabs may excavate and pelletize 500 tons.day $^{-1}$ and 20 tons.day $^{-1}$, respectively, over the

524 studied pioneer and young mangrove areas $\left(6 \mathrm{~km}^{2}\right.$, Fig. 1) during spring tides and dry seasons.

525 Thus, results suggest the potentially considerable contribution of the sediment reworking,

526 induced by crabs in the early mangrove development stages, to sediment re-distribution within

527 mangroves system as well as towards the adjacent estuary and open ocean (Botto and Iribarne,

528 2000; Botto et al., 2005; Gutiérrez et al., 2006; Escapa et al., 2008; Fanjul et al., 2014),

529 thereby contributing to the sedimentological and biogeochemical functioning of one of the

530 largest mangrove ecosystems in the Atlantic ocean.

\section{5. Conclusions}

532 This study highlights the links between mangrove early growth, specific and functional

533 composition of the crab community structure, and the impacts of bioturbation activities on

534 sediment reworking. The role of burrowing crab species in the sediment reworking process

535 tends to increase with mangrove growth. Sediment reworking activities are microhabitat-

536 specific in the pioneer mangrove, suggesting the role of morpho-sedimentary heterogeneity in 
determining ecosystem functioning. While the single-species bioturbation activities have received considerable scientific attention in the past, this study suggests that an improved understanding of the organisms' contribution to the sedimentary reworking processes can be gained by taking into account functional groups and species interactions. Crab-induced sediment reworking is likely to be a key sedimentary process in ecosystem functioning of the dynamic and resilient mangroves in French Guiana despite apparent lower crab biodiversity than in other mangroves.

\section{Authorship}

A.A., E.M., F.F., G.T. designed the study. A.A., E.M., T.S., A.G., M.T. collected or analyzed the samples. A.A., E.M. and T.S. contributed to the data treatment. A.A. wrote the manuscript to which all authors contributed substantially.

\section{Acknowledgments}

This project was funded by the French National Science Agency (BIOMANGO project: ANR-12-JSV7-0012-01 and LabexMER project: ANR-10-LABX-19), the French national program EC2CO-Biohefect/Ecodyn/Dril/McrobiEn (MAGUY project), the European Fund for Regional Development (ECOCOT project). A.Aschenbroich's $\mathrm{PhD}$ thesis was funded by the "Université de Bretagne Occidentale" (UBO). The authors thank IRD and CNRS Guyane, J. Printemps, S. Orseau, I. Bihannic, Z. Baumann, P. Pachelle, J. Devasa, V. Cuq, R. Walcker and O. Gauthier for technical support. The authors would like to thank the anonymous reviewers for their significant contribution to the improvement of the manuscript quality.

\section{References}

Amouroux JM, Tavares M (2005) Natural recovery of Amazonian mangrove forest as revealed by brachyuran crab fauna : Preliminary description. Vie milieu 55:71-79

Anderson M (2001) A new method for non-parametric multivariate analysis of variance. Austral Ecol:32-46 
Anthony EJ, Gardel A, Gratiot N, Proisy C, Allison MA., Dolique F, Fromard F (2010) The Amazon-influenced muddy coast of South America: A review of mud-bank-shoreline interactions. Earth-Science Rev 103:99-121

Ashton EC, Macintosh DJ, Hogarth PJ (2003) A baseline study of the diversity and community ecology of crab and molluscan macrofauna in the Sematan mangrove forest, Sarawak, Malaysia. J Trop Ecol 19:127-142

Bartolini F, Cimò F, Fusi M, Dahdouh-Guebas F, Lopes GP, Cannicci S (2011) The effect of sewage discharge on the ecosystem engineering activities of two East African fiddler crab species: Consequences for mangrove ecosystem functioning. Mar Environ Res $71: 53-61$

Bartolini F, Penha-Lopes G, Limbu S, Paula J, Cannicci S (2009) Behavioural responses of the mangrove fiddler crabs (Uca annulipes and U. inversa) to urban sewage loadings: Results of a mesocosm approach. Mar Pollut Bull 58:1860-1867

Bellwood O (2002) The occurrence, mechanics and significance of burying behaviour in crabs (Crustacea: Brachyura). J Nat Hist 36:1223-1238

Bernardino AF, Netto S a., Pagliosa PR, Barros F, Christofoletti R a., Rosa Filho JS, Colling A, Lana PC (2015) Predicting ecological changes on benthic estuarine assemblages through decadal climate trends along Brazilian Marine Ecoregions. Estuar Coast Shelf Sci $166: 74-82$

Bertness MD, Miller T (1984) The distribution and dynamic of Uca pugnax (Smith) burrows in a New England salt marsh. J Exp Mar Bio Ecol 83:211-237

Bezerra LA, Dias CB, Santana G, Matthews-Cascon H (2006) Spatial distribution of fiddler crabs (genus $U c a$ ) in a tropical mangrove of northeast Brazil. Sci Mar 70:759-766

Botto F, Iribarne O (2000) Contrasting Effects of Two Burrowing Crabs (Chasmagnathus granulata and Uca uruguayensis) on Sediment Composition and Transport in Estuarine Environments. Estuar Coast Shelf Sci 51:141-151

Botto F, Valiela I, Iribarne O, Martinetto P, Alberti J (2005) Impact of burrowing crabs on C and $\mathrm{N}$ sources, control, and transformations in sediments and food webs of SW Atlantic estuaries. Mar Ecol Prog Ser 293:155-164

Buchanan B a, Stoner a W (1988) Distributional patterns of blue crabs (Callinectes sp.) in a tropical estuarine lagoon. Estuaries 11:231-239

Buffan-Dubau E, Carman KR (2000) Extraction of benthic microalgal pigments for HPLC analyses. Mar Ecol Prog Ser 204:293-297 
Cannicci S, Fratini S, Vannini M (1999) Use of time, space and food resources in the mangrove climbing crab Selatium elongatum (Grapsidae: Sesarminae). Mar Biol $135: 335-339$

Cardinale BJ, Palmer M a, Collins SL (2002) Species diversity enhances ecosystem functioning through interspecific facilitation. Nature 415:426-9

Chapman MG, Tolhurst TJ, Murphy RJ, Underwood AJ (2010) Complex and inconsistent patterns of variation in benthos, micro-algae and sediment over multiple spatial scales. Mar Ecol Prog Ser 398:33-47

Colpo KD, Chacur MM, Guimarães FJ, Negreiros-Fransozo ML (2011) Subtropical Brazilian mangroves as a refuge of crab (Decapoda: Brachyura) diversity. Biodivers Conserv 20:3239-3250

Colwell RK, Chao A, Gotelli NJ, Lin SY, Mao CX, Chazdon RL, Longino JT (2012) Models and estimators linking individual-based and sample-based rarefaction, extrapolation and comparison of assemblages. J Plant Ecol 5:3-21

Crane J (1975) Fiddler Crabs of the World Ocypodidae: genus Uca. Princeton University Press, Princeton, New Jersey

Debenay J-P, Jouanneau J-M, Sylvestre F, Weber O, Guiral D (2007) Biological Origin of Rhythmites in Muddy Sediments of French Guiana. J Coast Res 236:1431-1442

Diele K, Koch V (2010) Comparative Population Dynamics and Life Histories of North Brazilian Mangrove Crabs, Genera Uca and Ucides (Ocypodoidea). In: Saint-Paul U, Schneider H (eds) Mangrove Dynamics and Management in North Brazil SE - 18. Springer Berlin Heidelberg, p 275-285

Diele K, Koch V, Abrunhosa FA, Farias Lima J, Jesus de Brito Simith D (2010) The Brachyuran crab community of the Caeté Estuary, North Brazil: species richness, zonation and abundance. In: Saint-Paul U, Schneider H (eds) Mangrove Dynamics and Management in North Brazil, p 251-263

Dittmann S (1995) Benthos structure on tropical tidal flats of Australia. Helgoländer Meeresunters 49:539-551

Doledec S, Chessel D (1994) Co-inertia analysis: an alternative method for studying speciesenvironment relationships. Freshwater Biology 31:277-294. Freshw Biol 31:277-294

Duport E, Stora G, Tremblay P, Gilbert F (2006) Effects of population density on the sediment mixing induced by the gallery-diffusor Hediste (Nereis) diversicolor O.F. Müller, 1776. J Exp Mar Bio Ecol 336:33-41 
Ellison AM (2008) Managing mangroves with benthic biodiversity in mind: Moving beyond roving banditry. J Sea Res 59:2-15

Escapa M, Minkoff DR, Perillo GME, Iribarne O (2007) Direct and indirect effects of burrowing crab Chasmagnathus granulatus activities on erosion of southwest Atlantic Sarcocornia-dominated marshes. Limnol Oceanogr 52:2340-2349

Escapa M, Perillo GME, Iribarne O (2008) Sediment dynamics modulated by burrowing crab activities in contrasting SW Atlantic intertidal habitats. Estuar Coast Shelf Sci 80:365373

Eshky A, Atkinson R, Taylor A (1995) Physiological ecology of crabs from Saudi Arabian mangrove. Mar Ecol Prog Ser 126:83-95

Fanjul E, Escapa M, Montemayor D, Addino M, Alvarez MF, Grela M a., Iribarne O (2014) Effect of crab bioturbation on organic matter processing in South West Atlantic intertidal sediments. J Sea Res 95:206-216

Ferreira AC, Ganade G, Luiz de Attayde J (2015) Restoration versus natural regeneration in a neotropical mangrove: Effects on plant biomass and crab communities. Ocean Coast Manag 110:38-45

Fromard F, Puig H, Mougin E, Marty G, Betoulle JL, Cadamuro L (1998) Structure, aboveground biomass and dynamics of mangrove ecosystems : New data from French Guiana. Oecologia 115:39-53

Fromard F, Vega C, Proisy C (2004) Half a century of dynamic coastal change affecting mangrove shorelines of French Guiana. A case study based on remote sensing data analyses and field surveys. Mar Geol 208:265-280

Gagic V, Bartomeus I, Jonsson T, Taylor A, Winqvist C, Fischer C, Slade EM, SteffanDewenter I, Emmerson M, Potts SG, Tscharntke T, Weisser W, Bommarco R (2015) Functional identity and diversity of animals predict ecosystem functioning better than species-based indices. Proc R Soc B Biol Sci 282:20142620-20142620

Gardel A, Gensac E, Anthony EJ, Lesourd S, Loisel H, Marin D (2011) Wave-formed mud bars: their morphodynamics and role in opportunistic mangrove colonization. J Coast Res:384-387

Gardel A, Gratiot N (2005) A Satellite Image-Based Method for Estimating Rates of Mud Bank Migration, French Guiana, South America. J Coast Res 21:720-728

Gensac E, Lesourd S, Gardel A, Anthony EJ, Proisy C, Loisel H (2011) Short-term prediction of the evolution of mangrove surface areas: The example of the mud banks of Kourou and Sinnamary, French Guiana. J Coast Res 64:388-392 
Gilbert F, Hulth S, Grossi V, Poggiale J-C, Desrosiers G, Rosenberg R, Gérino M, FrançoisCarcaillet F, Michaud E, Stora G (2007) Sediment reworking by marine benthic species from the Gullmar Fjord (Western Sweden): Importance of faunal biovolume. J Exp Mar Bio Ecol 348:133-144

Gotelli NJ, Colwell RK (2001) Quantifying biodiversity: procedures and pitfalls in the measurement and comparison of species richness. Ecol Lett 4:379-391

Gutiérrez JL, Jones CG, Groffman PM, Findlay SEG, Iribarne O, Ribeiro PD, Bruschetti CM (2006) The Contribution of Crab Burrow Excavation to Carbon Availability in Surficial Salt-marsh Sediments. Ecosystems 9:647-658

Von Hagen HO (1977) The Tree-climbing crabs of Trinidad. Stud. Fauna Curaçao 54: 25-59. 175

Hedges JI, Stern JH (1984) Carbon and nitrogen determinations of carbonate-containing solids. Limnol Oceanogr 29:657-663

Hirose GL, Negreiros-Fransozo ML (2008) Population biology of Uca maracoani Latreille 1802-1803 (Crustacea, Brachyura, Ocypodidae) on the south-eastern coast of brazil. Panam J Aquat Sci 3:373-383

Hooper DU, Chapin III FS, Ewel JJ, Hector A, Inchausti S, Lavorel S, Lawton JH, Lodge DM, Loreau M, Naeem S, Schmid B, Setälä H, Symstad AJ, Vandermeer J, Wardel DA (2005) Effects of biodiveristy on ecosystem functioning: a consensus of current knowledge. Ecol Monogr 75:3-35

Huang SC, Shih SS, Ho YS, Chen CP, Hsieh HL (2012) Restoration of Shorebird-roosting mudflats by partial removal of estuarine mangroves in Northern Taiwan. Restor Ecol 20:76-84

Iribarne O, Bortolus a., Botto F (1997) Between-habitat differences in burrow characteristics and trophic modes in the southwestern Atlantic burrowing crab Chasmagnathus granulata. Mar Ecol Prog Ser 155:137-145

Kathiresan K (2003) How do mangrove forests induce sedimentation? Rev Biol Trop 51:355359

Kent CPS, McGuinness K a. (2006) A Comparison of Methods for Estimating Relative Abundance of Grapsid Crabs. Wetl Ecol Manag 14:1-9

Kim TW, Kim KW, Srygley RB, Choe JC (2004) Semilunar courtship rhythm of the fiddler crab Uca lactea in a habitat with great tidal variation. J Ethol 22:63-68 
Koch V, Wolff M (2002) Energy budget and ecological role of mangrove epibenthos in the Caeté estuary, North Brazil. Mar Ecol Prog Ser 228:119-130

Koch V, Wolff M, Diele K (2005) Comparative population dynamics of four fiddler crabs (Ocypodidae, genus $U c a$ ) from a North Brazilian mangrove ecosystem. Mar Ecol Prog Ser 291:177-188

Kon K, Kurokura H, Tongnunui P (2010) Effects of the physical structure of mangrove vegetation on a benthic faunal community. J Exp Mar Bio Ecol 383:171-180

Kristensen E (2008) Mangrove crabs as ecosystem engineers; with emphasis on sediment processes. J Sea Res 59:30-43

Kristensen E, Alongi DM (2006) Control by fiddler crabs (Uca vocans) and plant roots (Avicennia marina) on carbon, iron, and sulfur biogeochemistry in mangrove sediment. Limnol Oceanogr 51:1557-1571

Lee SY (1998) Ecological role of grapsid crabs in mangrove ecosystem: a review. Mar Freshw Res 49:335-343

Lee SY (2008) Mangrove macrobenthos: Assemblages, services, and linkages. J Sea Res 59:16-29

Legendre P, Gallagher ED (2001) Ecologically meaningful transformations for ordination of species data. Oecologia 129:271-280

Li W, Cui L, Zhang M, Wang Y, Zhang Y, Lei Y, Zhao X (2015) Effect of mangrove restoration on crab burrow density in Luoyangjiang Estuary, China. For Ecosyst 2:21

Lorenzen CJ (1966) A method for the continuous measurement of in vivo chlorophyll concentration. Deep Res 13:223-227

Macintosh DJ, Ashton EC, Havanon S (2002) Mangrove Rehabilitation and Intertidal Biodiversity: a Study in the Ranong Mangrove Ecosystem, Thailand. Estuar Coast Shelf Sci 55:331-345

Marchand C, Baltzer F, Lallier-Vergès E, Albéric P (2004) Pore-water chemistry in mangrove sediments: Relationship with species composition and developmental stages (French Guiana). Mar Geol 208:361-381

Marchand C, Lallier-Vergès E, Baltzer F (2003) The composition of sedimentary organic matter in relation to the dynamic features of a mangrove-fringed coast in French Guiana. Estuar Coast Shelf Sci 56:119-130 
Mermillod-Blondin F, François-Carcaillet F, Rosenberg R (2005) Biodiversity of benthic invertebrates and organic matter processing in shallow marine sediments: an experimental study. J Exp Mar Bio Ecol 315:187-209

Miller DC (1961) The feeding mechanism of fiddler crabs with ecological consideration of feeding adaptation. Zoologica 46:89-100

Mokhtari M, Ghaffar MA, Usup G, Cob ZC (2015) Determination of key environmental factors responsible for distribution patterns of fiddler crabs in a tropical mangrove ecosystem. PLoS One 10:e0117467

Nagelkerken I, Blaber SJM, Bouillon S, Green P, Haywood M, Kirton LG, Meynecke J-O, Pawlik J, Penrose HM, Sasekumar a., Somerfield PJ (2008) The habitat function of mangroves for terrestrial and marine fauna: A review. Aquat Bot 89:155-185

Needham H, Pilditch C, Lohrer A, Thrush S (2010) Habitat dependence in the functional traits of Austrohelice crassa, a key bioturbating species. Mar Ecol Prog Ser 414:179-193

Nobbs M (2003) Effects of vegetation differ among three species of fiddler crabs (Uca spp.). J Exp Mar Bio Ecol 284:41-50

Nobbs M, McGuinness KA (1999) Developing methods for quantifying the apparent abundance of fiddler crabs (Ocypodidae: $U c a$ ) in mangrove habitats. Austral Ecol $24: 43-49$

Nordhaus I, Diele K, Wolff M (2009) Activity patterns, feeding and burrowing behaviour of the crab Ucides cordatus (Ucididae) in a high intertidal mangrove forest in North Brazil. J Exp Mar Bio Ecol 374:104-112

Penha-Lopes G, Bartolini F, Limbu S, Cannicci S, Kristensen E, Paula J (2009) Are fiddler crabs potentially useful ecosystem engineers in mangrove wastewater wetlands? Mar Pollut Bull 58:1694-1703

Proisy C, Gratiot N, Anthony EJ, Gardel A, Fromard F, Heuret P (2009) Mud bank colonization by opportunistic mangroves: A case study from French Guiana using lidar data. Cont Shelf Res 29:632-641

Scholander PF, Hammel HT, Hemmingsen E, Garey W (1962) Salt Balance in Mangroves. Plant Physiol 37:722-729

Skov MW, Hartnoll RG (2001) Comparative suitability of binocular observation, burrow counting and excavation for the quantification of the mangrove fiddler crab Uca annulipes (H . Milne Edwards ). Hydrobiologia 449:201-212 
757 Skov MW, Vannini M, Shunula JP, Hartnoll RG, Cannicci S (2002) Quantifying the density of mangrove crabs: Ocypodidae and Grapsidae. Mar Biol 141:725-732

759 Sperazza M, Moore JN, Hendrix MS (2004) High-resolution particle size analysis of naturally 760 occurring very fine-grained sediment through laser diffractometry: Research methods $761 \quad$ paper. J Sediment Res 74:736-743 
1 Table captions:

2 Table 1: Sediment characteristics (mean \pm SD) in the three microhabitats (tidal channel, flat,

3 pool) of both mangrove stands (pioneer and young) sampled in November 2014. Results of one-way ANOVAs (F and $p$-values) and of Kruskal-Wallis tests ( $\chi^{2}$ and $p$-values) using microhabitats within each mangrove age (a: pioneer; b: young) and mangrove age (c) as fixed factors. Only significant results $(p<0.05)$ are given. $n$ : number of samples per microhabitat.

Table 2: 'r' results and significance of Pearson's multi-correlation analysis between selected environmental variables $(n=15)$, crab density (D) and biomass $(\mathrm{Bm}) .{ }^{* * *} p<0.001,{ }^{* *} p<$ $0.01, * p<0.05$, ' ' refers to non-significant values at $p<0.1$. For readability, ' $\mathrm{r}$ ' values are not shown when $p>0.1$ (indicated by '-').

Table 3: Pearson's multi-correlations between sediment reworking rates and density (D) and biomasses $(\mathrm{Bm})$ of total community and functional groups or selected species $(n=15)$. Bulldozer: Callinectes bocourti; Non-burrowers: juveniles of Uca spp, Grapsidae spp. and Xanthidae spp.; Small burrower: adults of Uca spp.; Large burrower: Ucides cordatus. Within the small burrower group: $U$. cumulanta considered separately was significantly correlated with sediment reworking rates. ${ }^{* * *} p<0.001,{ }^{* *} p<0.01,{ }^{*} p<0.05$, ns: $p>0.05$.

\section{Figure captions:}

Fig. 1: Study site in the Northeastern part of the Sinnamary estuary in French Guiana investigated in November 2014. The shorelines as they were in 2009 and 2012, drawn after past satellite images analysis, are presented. The mud bank was colonized by pioneer trees in the lower part of the intertidal zone (pioneer mangrove) whereas a young mangrove has developed in the upper part. Pictures at the bottom illustrate the vegetation structure and the 
morpho-sedimentary microhabitats (pools, flat, tidal channels) identified in the pioneer and young mangroves and investigated in this study.

Fig. 2: Study design employed for the study of the changes of crab community structure and of their associated sediment reworking rates in relation to the stage of mangrove development (sites) and spatial heterogeneity (microhabitats). Microhabitats ( 3 pools, 3 flats, 3 tidal channels) identified in both sites (1 pioneer and 1 young mangroves) were investigated through the sampling of $3 \times 1 \mathrm{~m}^{2}$ plots in which the surface sediment parameters were characterized.

Fig. 3: Rarefaction curves A) based on the accumulated number of individual per stage of mangrove development, B) extrapolated and based on the sample area $\left(\mathrm{m}^{2}\right)$ per stage of mangrove development (pioneer and young mangroves) C) per microhabitats (pools, flat, tidal channels) as a function of the number of individual sampled in each plot. Dots along the curves mark the sampled plots. The black vertical arrow indicate the numbers of individuals used for comparison between sites and microhabitats $(A: n=130, C: n=37)$.

Fig. 4: Allometric relationships between the biomass $\left(\mathrm{Bm} ; \mathrm{g}_{d w}\right)$ and carapace length $(\mathrm{CL} ; \mathrm{mm})$ of Uca spp. $(n=183)(\mathrm{p}<0.001)$.

Fig. 5: A) mean density (D, ind. $\left.\mathrm{m}^{-2}\right)$ and $\left.\mathrm{B}\right)$ biomass $\left(\mathrm{Bm}, \mathrm{g}_{d w} \mathrm{~m}^{-2}\right)$ of crab species according to microhabitats in the two mangrove stages (young and pioneer) classified by functional group. Bars represent the standard deviation of the total mean density or biomass per microhabitat.

Fig. 6: Co-inertia analysis of 15 sedimentary variables and 12 crab species from 15 sampling plots collected in the three microhabitats (flat, pools and/or tidal channels) of the two stages 
of mangrove development (pioneer and young mangrove). (a) Ordination of samples (from 1 to 15) on co-inertia axes, using environmental variables (origin of the arrows) and crab community composition (arrowheads) co-inertia weights. (b) Contributions of the crab community composition (based on Hellinger-transformed abundance data; grey arrows) and environmental variables to the canonical space (black arrows, code given below). 'Group' denotes four taxa clustered too close to be distinguished: Uca vocator, Uca burgesi, Ucides cordatus and Grapsidae sp2. X.sp1= Xanthidae sp.1, G.sp3= Grapsidae sp.3, Pneumato = pneumatophore density; Pha.chl.a = Phaeo:Chl-a ratio; Clay = $\%$ clay; Mud $=\%$ mud, VF. sand $=\%$ very fine sand C.silts $=\%$ coarse silts; Med.GS $=$ median grain size, C.N = C:N ratio. $\mathrm{tc}=$ tidal channels, $\mathrm{ft}=$ flat and $\mathrm{pl}=$ pools

Fig.7: Mean (+ SD) sediment reworking rates $\left(\mathrm{g}_{d w} \cdot \mathrm{m}^{-2} \cdot\right.$ day $\left.^{-1}\right)$ due to crab activities within the three microhabitats (tidal channels, flat, pools) in the two mangrove ages (pioneer and young). The excavation and pelletization rates were taken into account, thus reflecting burrow maintenance and feeding activities, respectively. Asterisk '*' refers to groups significantly different $(p<0.01)$. 
Table 1

\begin{tabular}{|c|c|c|c|c|c|c|c|c|c|c|c|c|}
\hline \multirow[t]{3}{*}{ Variables } & \multirow[t]{3}{*}{$n$} & \multicolumn{5}{|c|}{ Pioneer Mangrove } & \multicolumn{4}{|c|}{ Young Mangrove } & \multirow{2}{*}{\multicolumn{2}{|c|}{ (c) }} \\
\hline & & \multirow{2}{*}{$\begin{array}{l}\text { Tidal channels } \\
\text { Mean SD }\end{array}$} & \multirow{2}{*}{$\begin{array}{c}\text { Flat } \\
\text { Mean } S D\end{array}$} & \multirow{2}{*}{$\begin{array}{c}\text { Pools } \\
\text { Mean SD }\end{array}$} & \multicolumn{2}{|l|}{ (a) } & \multirow{2}{*}{$\begin{array}{l}\text { Tidal Channels } \\
\text { Mean } S D\end{array}$} & \multirow{2}{*}{$\begin{array}{c}\text { Flat } \\
\text { Mean } S D\end{array}$} & \multicolumn{2}{|l|}{ (b) } & & \\
\hline & & & & & stat & $p$ & & & stat & $p$ & stat & $p$ \\
\hline \multicolumn{13}{|l|}{ Physical parameters } \\
\hline Median grain size $(\mu \mathrm{m})$ & 9 & 7.00 .3 & 7.20 .2 & 7.40 .4 & - & - & 7.00 .1 & 7.20 .3 & - & - & - & - \\
\hline Clay $(\%)$ & 9 & 22.31 .2 & 21.70 .8 & 21.11 .4 & - & - & 22.30 .6 & 21.51 .2 & - & - & - & - \\
\hline Mud (\%) & 9 & 72.21 .2 & 72.80 .7 & 71.61 .9 & - & - & 73.10 .4 & 73.20 .5 & - & - & $x^{2}=7.99$ & 0.004 \\
\hline Coarse silt (\%) & 9 & 3.80 .6 & 40.5 & 4.81 .1 & - & - & 3.40 .2 & 40.5 & $F=13.59$ & 0.002 & $F=8.50$ & 0.006 \\
\hline Very fine sand (\%) & 9 & 1.40 .4 & 1.20 .4 & 2.21 .2 & - & - & 0.90 .2 & 1.20 .4 & - & - & $F=9.68$ & 0.003 \\
\hline Water content (\%) & 9 & 36.93 .4 & 323.4 & 36.55 .3 & $F=3.96$ & 0.032 & 37.22 .7 & 41.91 .9 & $F=18.03$ & 0.001 & $F=16.81$ & 0.000 \\
\hline Porosity & 9 & 0.50 .1 & 0.50 .1 & 0.60 .1 & - & - & 0.50 .1 & 0.70 .1 & $F=12.31$ & 0.003 & - & - \\
\hline Salinity & 6 & 35.70 .7 & 38.31 .2 & 36.72 .2 & - & - & 28.71 .6 & 32.32 .1 & $F=8.56$ & 0.022 & $F=95.00$ & 0.000 \\
\hline \multicolumn{13}{|l|}{ Biological parameters } \\
\hline Pneumatophores density $\left(. \mathrm{m}^{-2}\right)$ & 3 & 0.00 .0 & 8.013 .8 & 0.00 .0 & - & - & 194.640 .1 & 568.7815 .2 & - & - & $X^{2}=11.94$ & 0.001 \\
\hline Litter $\left(\mathrm{g} d \mathrm{~d} \cdot \mathrm{m}^{-2}\right)$ & 3 & 0.10 .1 & 00 & 0.30 .3 & - & - & 42.3 & 6.23 .6 & - & - & $x^{2}=10.50$ & 0.001 \\
\hline $\mathrm{POC}\left(\mu \mathrm{g} \cdot \mathrm{mg}^{-1}\right)$ & 3 & 91 & 7.70 .1 & 100.2 & $F=11.42$ & 0.009 & 7.60 & 7.80 .1 & - & - & $x^{2}=4.01$ & 0.045 \\
\hline PON $\left(\mu \mathrm{g} \cdot \mathrm{mg}^{-1}\right)$ & 3 & 1.30 .1 & 1.20 & 1.50 .2 & - & - & 1.10 & 1.10 & - & - & $x^{2}=8.00$ & 0.005 \\
\hline $\mathrm{C}: \mathrm{N}$ ratio & 3 & 8.40 .1 & 8.20 .4 & 8.80 .6 & - & - & 8.50 .2 & 8.40 .1 & - & - & - & - \\
\hline Chl-a $\left(\mu g . g^{-1}\right)$ & 9 & 23.210 .9 & 14.66 .7 & 31.912 .6 & $F=6.78$ & 0.005 & 7.32 .1 & 5.81 .8 & - & - & $F=111.25$ & 0.000 \\
\hline Phaeo:Chl-a ratio & 9 & 0.70 .3 & 1.10 .5 & 0.50 .3 & $F=5.56$ & 0.010 & 20.6 & 2.40 .6 & - & - & $F=93.54$ & 0.000 \\
\hline
\end{tabular}


Table 2

\begin{tabular}{|c|c|c|c|c|c|c|c|c|c|c|}
\hline \multirow{2}{*}{$\begin{array}{l}\text { Variables } \\
\text { Physical parameters }\end{array}$} & \multicolumn{2}{|c|}{ Callinectes bocourti } & \multicolumn{2}{|c|}{ Goniopsis cruentata } & \multicolumn{2}{|c|}{ Uca cumulanta } & \multicolumn{2}{|c|}{ Uca maracoani } & \multicolumn{2}{|c|}{ Uca mordax } \\
\hline & $\mathrm{D}$ & $\mathrm{Bm}$ & $\mathrm{D}$ & $\mathrm{Bm}$ & $\mathrm{D}$ & $\mathrm{Bm}$ & $\mathrm{D}$ & $\mathrm{Bm}$ & $\mathrm{D}$ & $\mathrm{Bm}$ \\
\hline Median grain size $(\mu \mathrm{m})$ & - & - & - & - & $-0.57^{*}$ & $-0.55^{*}$ & - & - & - & - \\
\hline Mud (\%) & $0.54^{*}$ & 0.45 & - & - & $0.55^{*}$ & - & - & - & - & - \\
\hline Coarse silt $(\%)$ & $0.56^{*}$ & - & $0.53^{*}$ & 0.47 & $-0.67^{* *}$ & $-0.63^{*}$ & - & - & - & - \\
\hline Very fine sand (\%) & $0.63^{* *}$ & 0.49 . & $0.60^{*}$ & $0.57^{*}$ & $-0.70^{\star *}$ & $-0.66^{*}$ & - & - & - & - \\
\hline Water content $(\%)$ & - & - & - & - & - & - & $-0.53^{*}$ & - & $0.69^{* * *}$ & $0.71^{* \star \star}$ \\
\hline Porosity & - & - & - & - & - & - & - & - & $0.74^{* * *}$ & $0.74^{* \star \star}$ \\
\hline Salinity & - & - & - & - & $-0.68^{\star \star *}$ & $-0.71^{*}$ & $0.58^{*}$ & - & - & - \\
\hline Pneumatophores density $\left(. \mathrm{m}^{-2}\right)$ & - & - & - & - & - & - & - & - & $0.94^{* * *}$ & $0.90^{* * *}$ \\
\hline Biological parameters & & & & & & & & & & \\
\hline Litter $\left(\mathrm{g} \mathrm{dw} \cdot \mathrm{m}^{-2}\right)$ & - & - & - & - & - & - & - & - & $0.82^{* * *}$ & $0.84^{* \star *}$ \\
\hline POC $\left(\mu \mathrm{g} \cdot \mathrm{mg}^{-1}\right)$ & - & - & $0.61^{*}$ & $0.57^{*}$ & $-0.71^{* \star *}$ & $-0.67^{* *}$ & - & - & - & - \\
\hline PON $\left(\mu \mathrm{g} \cdot \mathrm{mg}^{-1}\right)$ & 0.46 & $0.66^{* *}$ & - & - & $-0.64^{* *}$ & $-0.63^{\star *}$ & - & - & - & - \\
\hline C:N ratio & - & - & $0.73^{* * *}$ & $0.67^{* \star}$ & - & - & $-0.52^{*}$ & - & - & - \\
\hline Chl-a $\left(\mu \mathrm{g} \cdot \mathrm{g}^{-1}\right)$ & - & $0.51^{*}$ & - & - & $-0.68^{* *}$ & $-0.66^{* *}$ & - & - & - & - \\
\hline Phaeo:Chl-a ratio & - & - & - & - & $0.65^{\star *}$ & $0.71^{* * *}$ & - & - & - & - \\
\hline
\end{tabular}


Table 3

\begin{tabular}{|c|c|c|}
\hline Functional groups & \multicolumn{2}{|c|}{ Sediment reworking rates } \\
\hline \multirow[b]{4}{*}{ Total community } & Excavation & Pelletization \\
\hline & $\mathrm{Bm}$ & $\mathrm{Bm}$ \\
\hline & & \\
\hline & $0.20^{\text {ns }} ; 0.99^{* * *}$ & $0.39^{\mathrm{ns}} ;-0.29^{\mathrm{ns}}$ \\
\hline \multicolumn{3}{|l|}{ Young Mangrove } \\
\hline Bulldozer & ; $\quad-$ & - \\
\hline Non-burrowers & $-0.24^{\mathrm{ns}} ; 0.16^{\mathrm{ns}}$ & $0.87^{*} ; 0.65^{\mathrm{ns}}$ \\
\hline Small burrowers & $0.90 * ; 0.89 *$ & $-0.42^{n s} ;-0.13^{n s}$ \\
\hline Uca cumulanta (only) & $0.76^{\mathrm{ns}} ; 0.70^{\mathrm{ns}}$ & $-0.24^{\mathrm{ns}} ; 0.03^{\mathrm{ns}}$ \\
\hline Large burrower & $0.99^{* \star \star} ; 0.99^{\star \star \star}$ & $-0.35^{\mathrm{ns}} ;-0.35^{\mathrm{ns}}$ \\
\hline \multicolumn{3}{|l|}{ Pioneer Mangrove } \\
\hline Bulldozer & $-0.52^{\mathrm{ns}} ;-0.40^{\mathrm{ns}}$ & $0.33^{\mathrm{ns}} ; 0.10^{\mathrm{ns}}$ \\
\hline Non-burrowers & $0.18^{\mathrm{ns}} ;-0.24^{\mathrm{ns}}$ & $0.29^{\mathrm{ns}} ; 0.59^{\mathrm{ns}}$ \\
\hline Small burrowers & $0.77^{*} ; 0.35^{\mathrm{ns}}$ & $-0.31^{n s} ;-0.51^{n s}$ \\
\hline Uca cumulanta (only) & $0.72^{*} ; 0.68^{\mathrm{ns}}$ & $-0.19^{\mathrm{ns}} ;-0.37^{\mathrm{ns}}$ \\
\hline Large burrower & - & - \\
\hline
\end{tabular}


Mangrove development

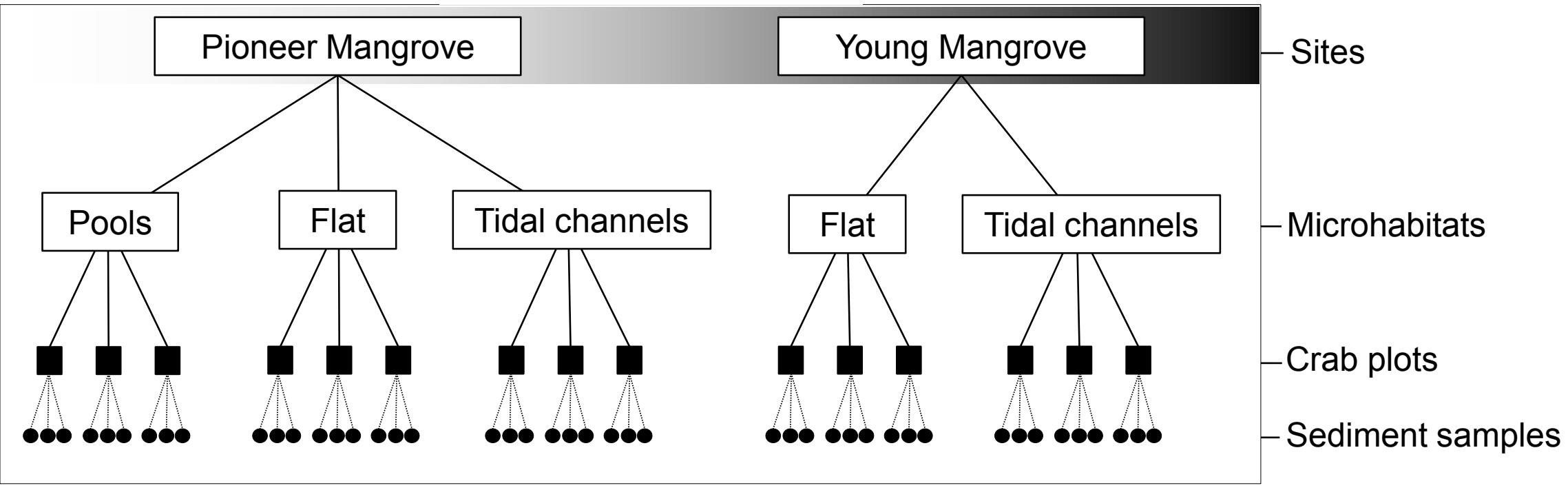




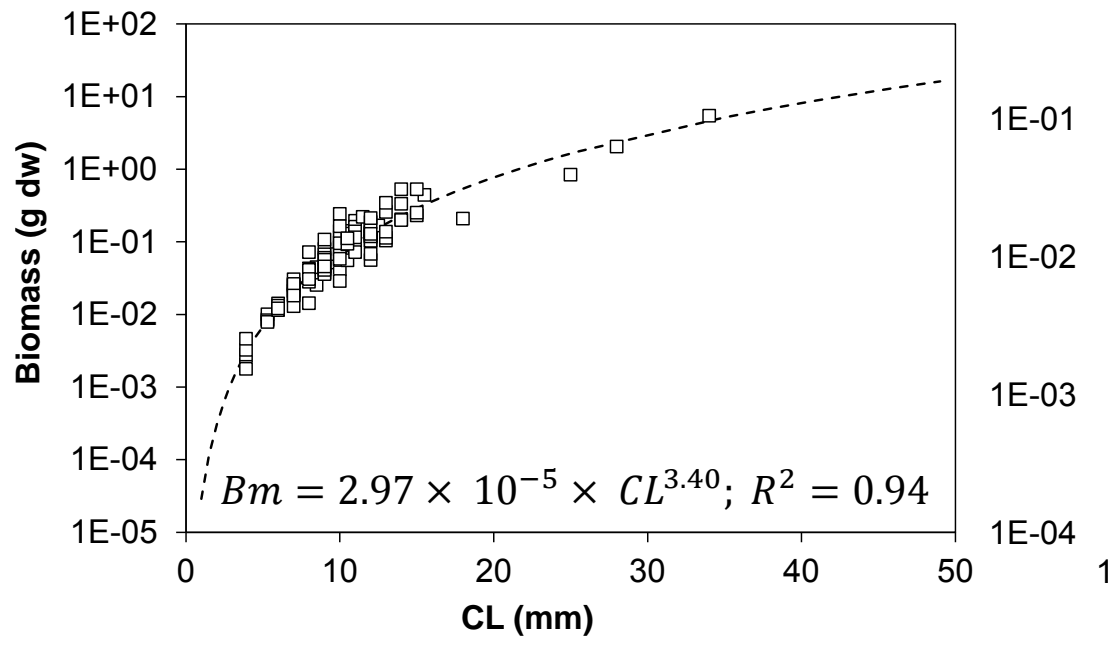




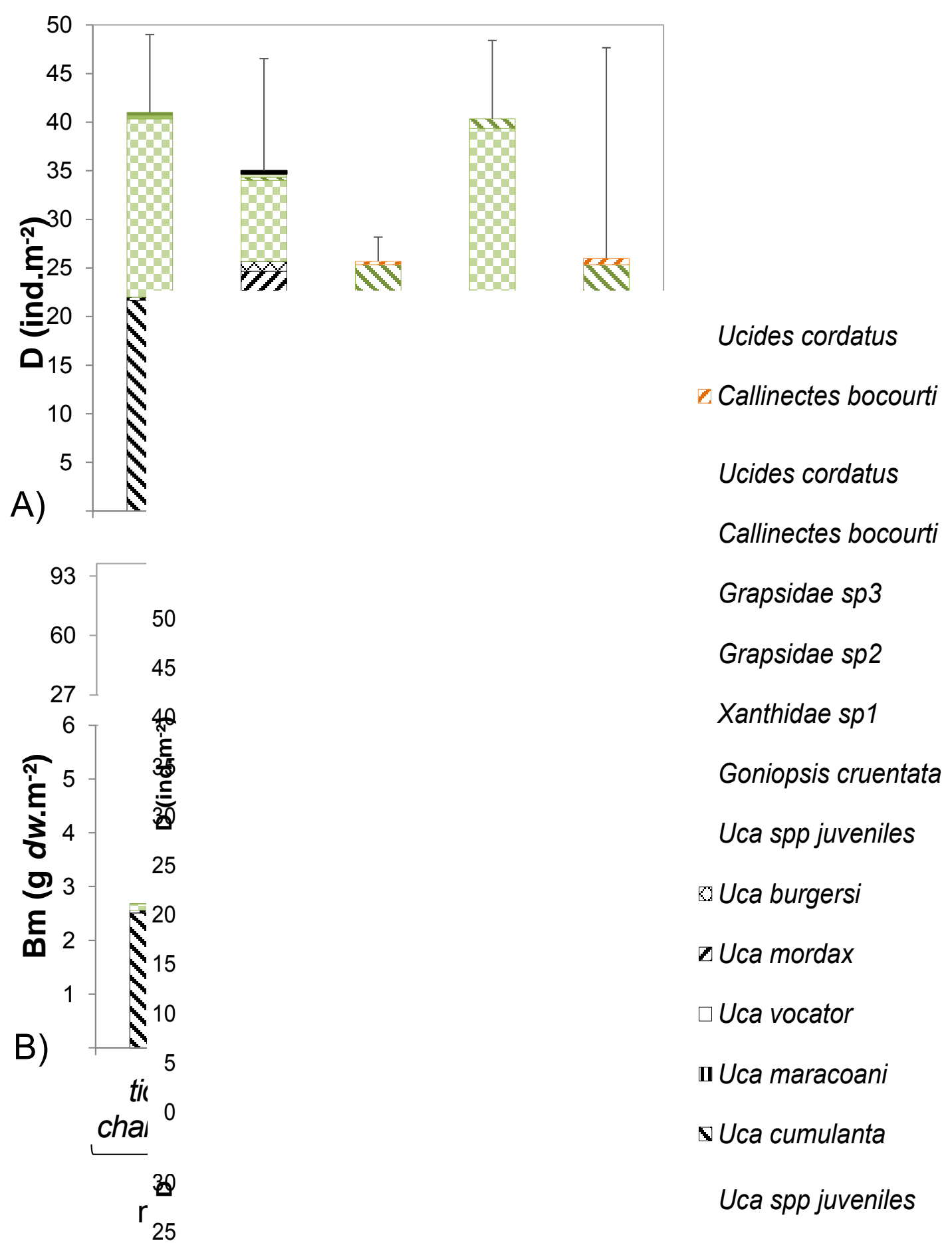




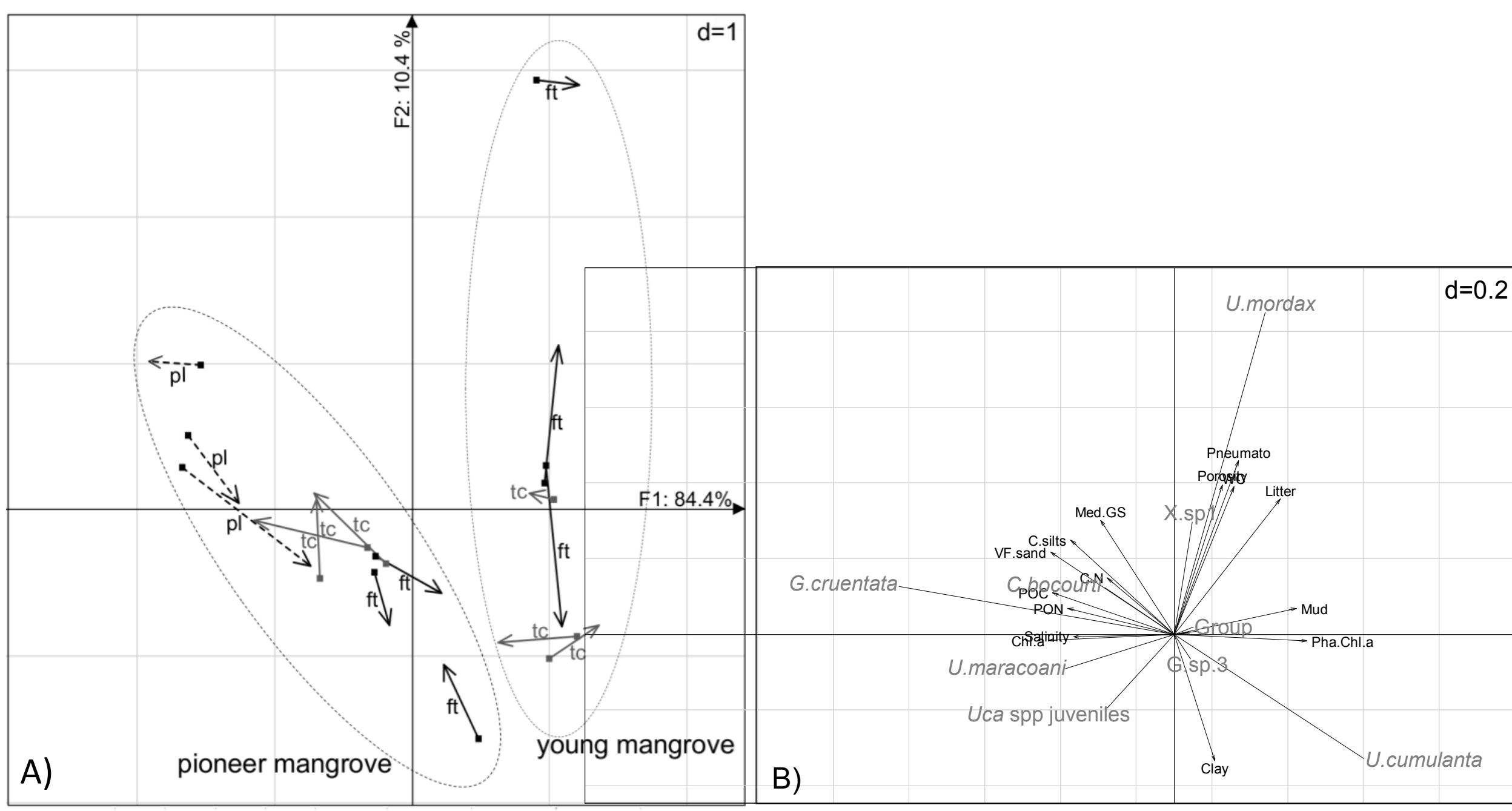

Fig.6 


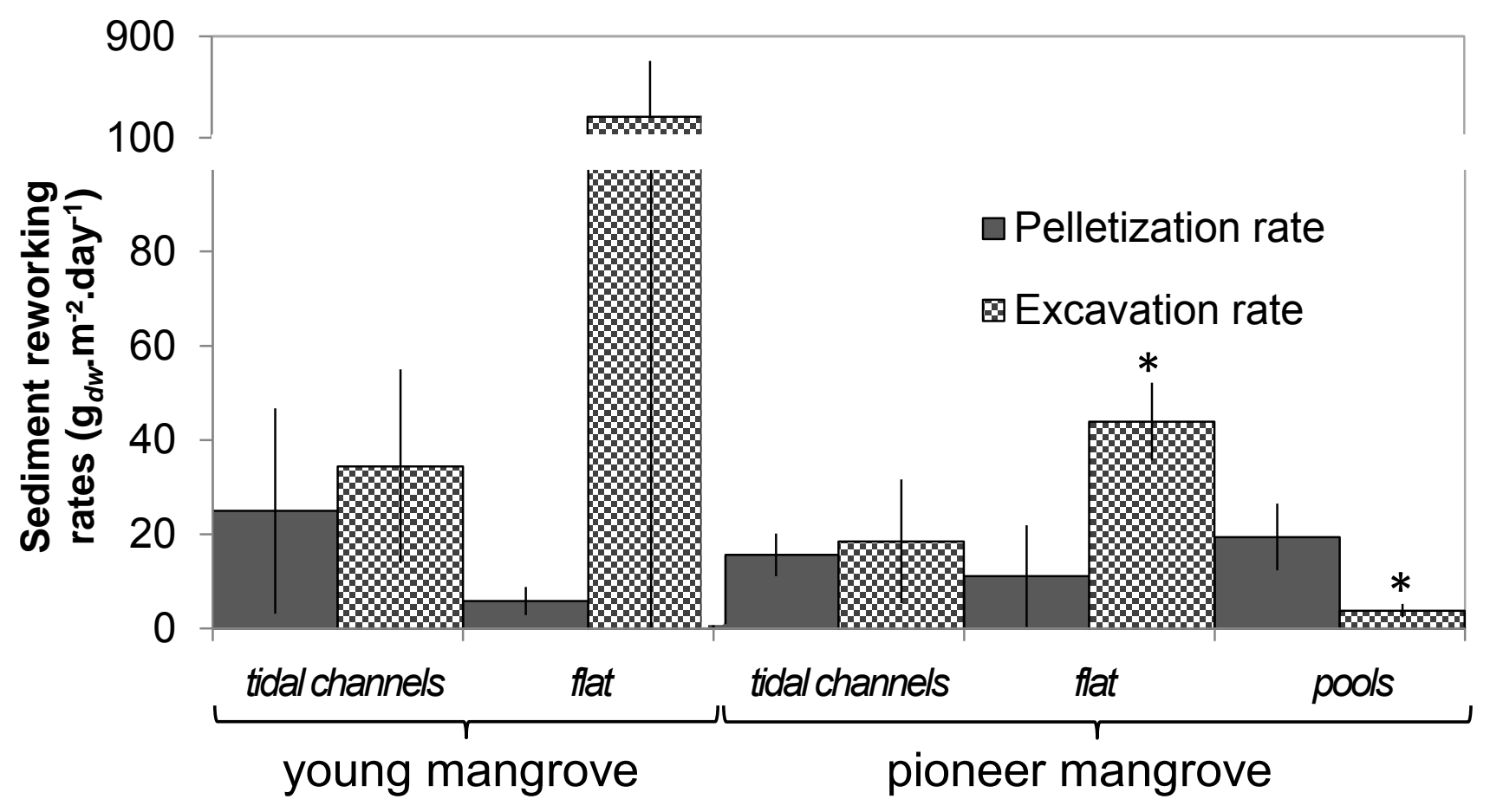

Fig.7 